\title{
Attribution Theories in Language Learning Motivation: Success in Vocational English for Hospitality Students
}

\author{
Laura V. Fielden ${ }^{1} \&$ Mercedes Rico ${ }^{1}$ \\ ${ }^{1}$ Department of English Philology, University of Extremadura, Spain \\ Correspondence: Laura V. Fielden Burns, Department of English Philology, University of Extremadura, Badajoz, \\ Spain. Tel: 34-924-289-300. E-mail: 1vfielden@unex.es
}

Received: January 16, 2018

Accepted: October 6, 2018 Online Published: October 10, 2018

doi: $10.5539 /$ elt.v11n11p44

URL: http://doi.org/10.5539/elt.v11n11p44

\begin{abstract}
One of the overlooked motivational areas for VET hospitality students learning English is attribution theories, students' beliefs about why they fail or succeed. Weiner identified four basic attributions that people tend to have in achievement situations (2010; 1984): ability, effort, task difficulty, and luck, which contribute to students' motivation to study. With the aim of researching motivation in order to prevent program abandonment, which is high in Spain, this 2-phased study examined attribution theories for a group of 51 adult, English for hospitality students studying in vocational courses offered by the public employment agency in Extremadura, Spain. It found that in general students' attribution theories were mostly negative, though they strongly indicated that they could improve through effort. These results may be associated with students' perception of the instructor and course and the social, dynamic nature of students' beliefs in general as they are formulated in situ. Suggestions are made for incorporating this possible influence into future vocational course visions for English for hospitality students.
\end{abstract}

Keywords: motivation, attribution theories, vocational adult English, hospitality, Spain

\section{Introduction}

Among the many vocational areas that make up the world of English for specific, occupational or vocational purposes (Dudley-Evans \& St. John, 1998), that of English for tourism and hospitality studies shows special relevance for job seekers today. This sector is the key to the economic recovery in many countries (Bharwani \& Butt, 2012; World Travel and Tourism Council, 2015) and particularly in Spain, where unemployment remains high at $18.91 \%$ (Instituto Nacional de Estadística, 2016). The World Economic Forum listed Spain as the most competitive travel and tourism country in 2015 (World Economic Forum, 2015) and employment in the tourism sector in Spain contributed to 1 in 7 jobs in 2015 when the sector grew $3.7 \%$ over the previous year by seeing a record number of visitors to the country, 68 million in 2015 (Costantini, 2016).

For this reason, vocational training courses certified by the government in tourism and hospitality are in demand in Spain, programs that require passing at least one English module (90-120 hours) focusing on language competence, important to mobility in the field of vocational training (Tran \& Nyland, 2013). Yet, despite the dire economic situation and the demand for such programs, the drop-out rate still seems to be quite high in vocational education in the peninsula (Ministerio de Educación, Cultura y Deporte, 2016; Refernet Spain, 2013; Comas-Forgas et al., 2015). Indications are that in part this drop-out rate is due to problems with motivation (Comas-Forgas et al., 2015; ReferNet, 2013; European Commission, 2013; Mulder, Kahmann, Laubenbacher, \& Messmann, 2006). However, studies do not often discuss what sort of motivational issue should be focused on. This investigation aims to improve our understanding of vocational English learners' motivation in Spanish hospitality students. Specifically, it will examine students' attribution theories, what they attribute their success or failure to, in an English course for hospitality.

The application of attribution theory could help to explain some of students' motivational problems, including "disengagement" (Fernández, Mena, \& Riviere, 2010) from the learning system, as other scholars in vocational training have indicated (Ingle \& Duckwort, 2013; Wang, 2012). Concretely, attribution beliefs point toward how much students may feel in control of their learning process, so they can better "[ ] recognize links between effort and outcome; and attribute past failures to controllable factors such as insufficient effort (if this has been the case), confusion about what to do, or the use of inappropriate strategies, rather than to lack of ability, as this may 
lead to learned helplessness (Dörnyei, 1994)".

If vocational instructors have a better understanding of attribution theory for language learners, they can help steer students' motivation in constructive ways and encourage their class attendance and course completion, since research suggests that teachers can intervene to help improve students' motivation (Dörnyei, Henry, \& Muir, 2016; Dweck, 2000). Deconstructing attribution theories are helpful to the students themselves, allowing them to get a better grasp on what they perceive as within their realm of control in English learning, creating self-awareness and helping students set realistic course goals and study plans.

Few studies have been done on attribution theories and vocational students, and as such it is an area in need of more scholarly focus. The benefits of positive attribution are of particular relevance to this population given the high rate of vocational program drop-out. Additionally, the hospitality/tourism sector is an understudied but large and growing population contributing to economic growth in Spain. We will contribute as well to a greater understanding of the motivation and beliefs of students in countries of particular economic difficulty.

\section{Background}

\subsection{The Spanish Context}

Vocational training programs made up $42.5 \%$ of all secondary education enrollments in Spain in 2006, which means that enrollments nearly doubled from 1998 (Jordan, Lamamra, \& Masdonati, 2009). One of the larger vocational programs is tourism and hospitality, one that requires students to take enough English to reach an "independent level" in order to interact with clients (Boletín Oficial de Estado, 2009). However, there is a generally negative sentiment in and about Spain where studying English is concerned. European Union public opinion surveys indicate that Spain recognizes English as the most important language to learn, but is behind other EU members in its use, where only $22 \%$ of Spanish over the age of 18 indicate they are able to speak English (the average in the EU is 38\%) (European Commission, 2012). A quick look at Spanish news sources on the topic reveal a common social perception that the Spanish are not good at languages (Ibáñez \& Saurí, 2013; El Economista, 2015). This is important to Spain's still weak economy, because, as Baum (2012) notes, language skills make the difference in determining which workers can move forward in hospitality positions, since a lack of language skills means being relegated to menial tasks.

Nowadays job boundaries are blurring, and there is a need to consider many different types of educational sectors over one's lifetime (Harris \& Ramos, 2012), which has contributed to VET programs' growth. However, there is also an important perception of status differentiation between vocational programs and other academic programs in Spain. Though Spanish society tends to regard occupational training programs as mostly positive, $41 \%$ agreed with the statement: "Vocational education and training leads to jobs which are not well regarded in society" (Eurobarometer, 2011). Also, despite very high approval ratings as an educational option in the majority of EU countries, including Spain, most Spanish respondents indicated that they would recommend traditional academic tracks such as secondary school or higher education, over vocational programs by a margin of $37 \%$ to $30 \%$, which is higher than the overall EU rate (ibid, 8). Graduation rates for the 2013-2014 year in intermediate vocational programs was only around $60 \%$ overall and in advanced levels $72.5 \%$ (Ministerio de Educación, Cultura y Deporte, 2016). Students enrolled in Hospitality and Tourism at the intermediate level in 2013-2014 finished only $74.8 \%$ of their course modules (ibid, 13).

The pressure to learn English coupled with a negative sentiment about their ability to use it, and a somewhat negative perception of vocational training in general, affects Spanish hospitality students' motivation to study, as the current Director of the Extremaduran Hospitality College, L. Rocha, expressed in a telephone interview (2017). She referred to students' motivational problems and excessive miedo escénico (stage fright) in using English. Specifically, demotivation may be a key component to why vocational students leave their programs in Spain. In a pilot study with vocational students in Mallorca, Spain, $25 \%$ of enrolled students indicated that they were thinking of leaving their current program and listed motivation and academic performance as the principal factors for this consideration (Comas-Forgas et al., 2015).

\section{Theoretical Groundwork}

\subsection{Motivation}

Motivation has long been considered by certain academic contingents as one of the most important factors for successful language acquisition, beginning early on with seminal research by Gardner (Gardner, 1985; Gardner, 2009). Motivation is multi-faceted, and numerous scholars have contributed to defining its distinct branches. For example, negative beliefs about self-efficacy, the belief in one's effectiveness in achieving goals, are more common for occupational/vocational students (Kim, 2008). Van Houtte, Demanet, and Stevens (2012) found that 
vocational students are more likely to suffer problems with motivation related to lower self-esteem. In particular, the hospitality sector is an area where motivation in general is often under scrutiny given the unusually high turn-over rate in the field (Yang, Wan, \& Fu, 2012; Dipietro \& Condly, 2007). Hutchinson and Waters write that the English for Occupational Purposes world often overlooks the importance of motivation (Hutchinson \& Waters, 1987).

\subsection{Motivation: Language Learning Beliefs: BALLI Instrument}

Students' language learning beliefs, that is, their "opinions on a variety of issues and controversies related to language learning" (Horwitz, 1988) make up a key branch of motivation in second language acquisition. Barcelós (2003) extended the definition of LLB as "opinions or ideas about the task of learning a foreign or second language, these being socially constructed" (p. 231). The instrument most used to analyze LLB has been Horwitz's Beliefs about Language Learning Inventory (BALLI), (1988) which includes (1) foreign language aptitude, (2) difficulty of language learning, (3) nature of language learning, (4) learning and communication strategies, and (5) motivation and expectation. However, this instrument does not contemplate individual attributions, which are important to understanding how students interpret their success or trouble in language learning.

\subsection{Motivation: Language Learning Beliefs and Attribution Theories in the English VET Learner}

Attribution theories, sometimes termed explanatory theories or explanatory styles, are a subset of language learning beliefs that affect motivation. Based on Weiner $(1984 ; 2010)$, it is a particular branch of motivation studies, developed in the setting of education, which examine what students believe about their success or failure in a given area. Weiner identified four basic attributions that people tend to have in achievement situations: ability, effort, task difficulty, and luck, and which may later be projected onto other future learning situations. Weiner's further studies elaborated on these to emphasize not only the cause for success or failure, but also the locus of control related to that cause, in particular if the locus was internal or external. If someone attributes failure to an outside and, importantly, inalterable force that is beyond one's control, his or her sense of controlling achievement may be affected. By the same token, perceiving one's success as internal and under one's control may motivate achievement.

Attribution theory has been studied in second and foreign language acquisition in general but to a much lesser degree in vocational learners. $\mathrm{Wu}$ (2011), focusing on gender difference, studied attributions of Chinese students and found that the majority of these vocational students found stable, internal and controllable factors as the reasons for their success in English learning, as well as unstable, external and uncontrollable factors as the reasons for their problems in English learning. She found that no gender differences existed for attributions. Youchang (2007) found that Chinese vocational learners' incorrect attributions concerning their failures in English may exert a negative impact on their subsequent learning motivation. Tynjala and Virtanen (2008) found in an internet study $(\mathrm{N}=3,106)$ of general vocational learners that "students' perceived success in workplace learning is not only dependent on students' individual motivational factors but rather on the interplay between individual and social aspects of workplace learning" indicating that students attributed their success both to themselves and their learning environment. Other scholars have emphasized the social construction of beliefs in the classroom, where beliefs develop and are negotiated as a result of socio-cultural forces in the interplay between instructor and students (Barcelos, 2011).

Students who have positive attributions, who feel more intrinsically in control of their learning process, are clearer on their study goals and how to achieve them (Dweck, 2000). They also tend to be higher achieving and persist in language study (Peacock, 2010; Graham, 2004; Hsieh \& Schallert, 2008), which could logically lead to higher success rates in terms of actual language proficiency and thus later on-the-job performance. Anxiety from evaluations or performance events has been shown to negatively affect attributions (Dweck, 2000; Arkin, Kolditz, \& Kolditz, 1983).

\section{Research Questions and Objectives}

To summarize, motivation for foreign language acquisition is a very thoroughly studied field, but it is not often examined within the English for vocational purposes scope and rarely looked at in terms of its importance to learners in the hospitality sector, in particular, despite the importance of the field in today's economy. Attribution theories may be particularly important if effort attributions contribute to study persistence and general achievement, which would feasibly contribute to lowering the high drop-out rate in vocational programs. For this reason, the topic of this study focused on two areas of attribution: contribution to one's progress through effort and feeling positive about and in control of one's learning, which lead to higher motivation. We pose the following research questions, adapted from Dweck (2000, Annex): 
1) Do students feel positively about their English language skills in general?

2) Do students believe that they can contribute to their language progress with their efforts?

Finally, given that anxiety affects attributions (Dweck, 2000) and there is a pressure factor for using English on the job in this sector, we asked:

3). Do students' responses change under stress, such as when taking an exam?

\section{Method}

\subsection{Participants}

The participants were adults taking vocational courses in a public hospitality school in Extremadura, Spain, a region with one of the highest rates of unemployment and where national tourism, culture and gastronomy are directly responsible for more than 5\% of the regional GDP (not counting other sectors dependent on tourism, like commerce) (Hosteltur, 2014). The hospitality school was selected because it is the newest center for vocational training in Extremadura, as well as a designated certification center for vocational government courses. Learners came from two courses: English For Restaurant Service (A1-A2 level, $90 \mathrm{hrs)}$ and English for Tourism (A2, 120 hrs) making for a total of $51(\mathrm{~N}=51)$ participants in the sample group. This sample size is appropriate for a non-parametric study.

The students took part in the study voluntarily and were made up of a diverse range of ages and educational backgrounds. A little less than half of the group was university-educated $(\mathrm{N}=22)$, followed by high school studies (university prep) $(\mathrm{N}=14)$ and technical or vocational certificates $(\mathrm{N}=10)$. A wide variety of age groups were represented in the participant population, with a large group of 35 and under $(\mathrm{N}=33)$, but also with a wide band of persons between 36-40 years of age. There were more women $(\mathrm{N}=29)$ in the group than men.

\subsection{Instruments and Materials}

The materials utilized to look at student attributions were a Student Opinion Questionnaire designed for this purpose, and an English level test used in the school to gauge students' English levels. The questionnaire was given out on the first day of class, and then repeated when students took the level test.

\subsubsection{English Level Test}

The level test was merely a practice test to gauge the levels of the students for the teacher's information, and did not affect students' status in the program. Since attributions are most revealed within specific achievement events which may cause stress (Dweck, 2000), students' taking the level test was a key moment in which to determine if students' attributions changed. Stress is medically defined as any change in the homeostasis of an individual because of a perceived threat (Schneiderman, Ironson, \& Siegel, 2005).

\subsubsection{Student Opinion Questionnaire}

The second instrument, the Student Opinion Questionnaire, was created by the authors in Spanish (the students' native tongue) and included several areas pertinent to student beliefs and motivation. The questionnaire was first tested in a pilot group of 21 different students from the same courses the semester previous. Also, volunteer English students took the questionnaire using the "think-aloud" method to aid in item construction and coherence (Lewis, 1982).

\subsubsection{Test Reliability}

The Student Opinion Questionnaire was tested for reliability once the pilot phases had been finished. The ratio used for this purpose was Cronbach's alpha (Triola, 2006), indicating internal consistency of items, which is appropriate for non-parametric studies and small samples. The majority of experts agree that the standard for test reliability begins at 0.6 (Malhotra, 2004). The calculation performed with pre-test variables in this study show a value of 0.806 . Since the post-test contained variables that were not included on the pretest, the calculation was repeated for the second phase as well, concluding with a 0.795 alpha, which can be considered appropriate. Finally, construct validity was obtained by allowing two experts in the field of psychology familiar with the constructs and the purpose to review the questionnaire and make comments and suggestions.

\subsubsection{Response Format}

The response format was a semantic differential scale (Osgood, 1957) asking respondents to signal their answers by marking one spot on an unnumbered continuum. These scales are similar to Likert scales in that by adding up individual items one can reach a multi-item score. 
To address research objectives 1 and 2 the following variables related to self-efficacy and control were investigated. Students were asked how they felt about their English levels and how much they felt they were in control over its progress, if that progress was ultimately capped in some way, or limited, and if overall their English could be improved. Essentially, this query treated students' basic perception of the strength and malleability of their English skills. Items were adapted from Dweck (2000).

In terms of my current English level, I feel:

Good: $\square: \square: \square: \square: \square: \square: \square:$ Bad

In control: $\square: \square: \square: \square: \square: \square: \square$ : Out of control

Improvable: $\square: \square: \square: \square: \square: \square: \square$ : Not improvable

Limited: $\square: \square: \square: \square: \square: \square: \square:$ Unlimited

To address research objective 2, students were queried about how their success or failure might come about:

When I have trouble with English it is due to:
Lack of talent:
: lack of practice
Lack of gift:
: lack of effort

When I progress in English it is due to:

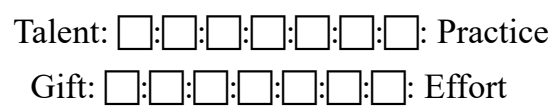

These variables referred to student trouble and progress in English and were included in order to understand how static or malleable students felt their abilities were and thus if their locus of control, being internal in this case, was in their hands, i.e.., if they saw their difficulties as a result of a lack of something innate that they might not have any control over (talent or a gift for languages) or something they could control themselves, such as a lack of practice, or effort. The same was asked of their beliefs about their progress, and whether it came about due to their effort or something innate and given (a gift, etc).

\subsection{Procedure}

Table 1. Phases of study administration

\begin{tabular}{ll}
\hline Phase 1: First day of class & 1) Student Opinion Questionnaire with demographic section \\
\hline Phase 2: 20-25 class hours after first class & 1). Basic Level Test \\
& 2). Student Opinion Questionnaire \\
Phase 3: & Data analysis
\end{tabular}

\subsection{Analysis}

As in any statistical study, when interesting data emerged exploratory data analysis was performed to confirm, utilizing the techniques of descriptive statistics and providing visual graphics where feasible through SPSS software, version 19.0. Descriptive statistics, which quantitatively describe the main features of a collection of data, offer an initial idea of the information contained in the variables under consideration in terms of their magnitudes and the differences between them. What follows are hypotheses about the data, in the form of statistical analysis that allows one to decide whether the data confirm or reject the initial hypothesis. Since the variables of the Phase 1 and 2 questionnaires are measured here on a scale of 1 to 7 , these being assigned to each box on the Semantic Differential visual scale, these can be considered ordinal variables. This determines the kind of contrast that can be used.

\section{Results}

\subsection{Opinion Questionnaire}

Attribution theories include the locus of control and the degree to which control is felt to be had over an outcome, since feeling that one's successes or failures are within one's control has a positive effect on achievement. In this study, to treat objective number 1, the questionnaire block referred to as "My present level of English" examined first confidence in English in general, and then, to reach objective number 2, areas of particular significance to 
error-progress attribution, such as students' feelings of control over their English learning, its limitations, and its ability to be improved in general. These variables were considered both pre- and post-stress test, so that students' responses could be examined within an achievement event, which was an English level test. Here on the 7-point, semantic differential scale 7 was the most positive for attributions, and 1 was the most negative.

In the table below (Table 2) one can see the students' responses to these items concerning the first objective, in both the pre- and post-test, where the negative responses (students' feeling bad about their English, out of control, etc.) are listed in the first column:

Table 2. How students feel about their present level of English*

\begin{tabular}{|c|c|c|c|c|c|c|c|}
\hline & Value 1 & Value 7 & Mean & Median & $\mathrm{SD}$ & $t$ & P-Value \\
\hline 1.5.5 Pre & Bad & Good & 2.5 & 2.0 & 1.3 & -1.427 & 0.087 \\
\hline 2.5.5 Pos & & & 2.4 & 2.0 & 1.4 & & \\
\hline 1.5.6 Pre & Out of control & In control & 3.3 & 4.0 & 1.4 & -0.446 & 0.334 \\
\hline 2.5.6 Pos & & & 3.1 & 3.0 & 1.7 & & \\
\hline 1.5.7 Pre & Not Improvable & Improvable & 6.3 & 7.0 & 1.1 & -3.035 & 0.001 \\
\hline 2.5.7 Pos & & & 6.7 & 7.0 & 0.6 & & \\
\hline 1.5.8 Pre & Limited & Unlimited & 3.6 & 3.0 & 2.1 & -0.952 & 0.175 \\
\hline 2.5.8 Pos & & & 3.8 & 4.0 & 2.1 & & \\
\hline T1.5.58 Pre & & & 3.9 & 4.0 & 1.0 & -0.953 & 0.173 \\
\hline T2.5.58 Pos & & & 4.0 & 4.0 & 1.1 & & \\
\hline
\end{tabular}

* $\mathrm{P}<0.00 \mathrm{P}<0.01$.

It is interesting to see above in the mean column how the whole group started from what can be inferred as low confidence in their level of English, which has been shown to be a concern in vocational students (Kim, 2008; Van Houtte et al., 2012). This is visible in the item "My English is bad/good," which shows a pre-test mean of 2.5 and a median of 2.0. This speaks to students' general sense of efficacy in the language. There was also a tendency to see their English levels as not within their control, with means of 3.3 and 3.1, which speaks to students' sense of reach, the degree to which they can have a hand in their progress. They also saw their English as quite limited, with means of 3.6 and 3.8, pre- and post-test. This item looks toward the degree to which students' skills may grow. It is noteworthy as well that two of these three items decrease with the stress test, with the exception of the item noting their English as "Limited". From these results students seem to feel quite negatively overall about their English skills and their control over it, both pre- and post-test, a feeling that was common in the group despite having different educational backgrounds or English language experience, since no significant differences were found for sex, age, educational level or English experience.

However, students also indicated that their English was very improvable, since the scores for the item "Improvable" are quite dramatically different from the other items, with pre- and post-test means of 6.3 and 6.7, respectively. So, students indicated that although they did not feel confident about, with great reach in, or even in control of, their English levels, they did feel that these could be improved.

Analysis was done using the Wilcoxon analysis (Triola, 2006) for signed pairs to determine if the pre- and post-test results for this block were significantly different, and only one item showed significant differences at a 95\% confidence level, which was the item (English can be improved), which reiterates the importance of this variable. This item increased in the post-test with a p-value of 0.001 . This response indicates that after an achievement event, students felt even more strongly than before that their English could be improved, which will be discussed in the next section.

Finally, students' beliefs concerning their success (termed progreso, or progress in the items) or failure (termed problemas or trouble in the items) with English when both of these were presented as internal were examined. Here the degree to which this internal source of trouble or progress was malleable or able to be changed, and thus controlled, was in focus. If it is considered an innate talent, it cannot be changed; whereas if it is seen as learned and influenced by effort and practice, it feasibly can be. 
The three variables that reflect the averages of each of these were calculated. The hypothesis contrast between the pre-test and the post-test showed that there was no significant change for these items between pre- and post-test, as can be seen in table 3 below.

Table 3. How students see their success or failure in English

\begin{tabular}{llllllll}
\hline & Value 1 & Value 7 & Mean & Median & SD & t & P-value \\
\hline Pre 1.5.1 & Trouble: & Trouble: & 5,94 & 6.00 & 1.028 & -.301 & .764 \\
Post 2.5.1 & Talent & Practice & 6.00 & 6.00 & 1.249 & & \\
Pre 1.5.2 & Trouble: & Trouble: & 5,24 & 5.00 & 1,193 & $-1,894$ & .058 \\
Post 2.5.2 & Gift & Effort & 5,55 & 6.00 & 1,447 & & \\
Pre 1.5.3 & Progress: & Progress: & 6,33 & 6.00 & 564, & $-2,502$ & .012 \\
Post 2.5.3 & Talent & Practice & 6,63 & 7.00 & 792 & & \\
Pre 1.5.4 & Progress: & Progress: & 6,25 & 6.00 & 1,017 & $-2,430$ & \multirow{2}{*}{015} \\
Post 2.5.4 & Gift & Effort & 6,61 & 7.00 &, 568 & & \\
Pre & Total & Total & 6,294 & 6.00 &, 7627 & $-2,676$ & \multirow{2}{*}{007} \\
T1.5.34 & & & 6,618 & 7.00 &, 5531 & & \\
Post & & & & & & \\
T2.5.34 & & & & & & &
\end{tabular}

$\mathrm{P}<0.00 \mathrm{P}<0.01$.

From these results one notes that after the stress test, students did not change their responses. They continued to believe that if they have trouble with or show progress in English, this is due more to lack of effort than to lacking a gift for the language. This is positive in that it indicates personal accountability and a sense of active investment in their learning. In the pretest, all four variables gave a high score, around six. In the post-test, this view was even further reinforced (65\% of students scored the item Effort with a seven), though, again, the difference was not significant. So, these students mostly saw their efforts as propellers for their progression and as a resource to resolve their difficulties (if one is having trouble, more effort is needed). This indicates the perception of an interior, manageable, locus of control, which is positive. It means students may feel that their efforts have some hand in their progress and can have an influence on the outcome, even under stress in an achievement event.

However, this is in contrast to the previous items where students indicated that they personally felt out of control and badly about their English levels. Perhaps this was due to an association being made between the concepts of improvement and progression, where students saw progression as the act of improvement and thus extended controllable qualities to it in the same way.

\section{Discussion}

\section{1 "My English currently": Objectives 1 and 3}

With respect to Objective 1, which looked to students' beliefs about their current state of English before and Objective 3, which examined these again after a stressful achievement event, the results showed that students did not seem to feel very confident about their English, a characteristic noted in other studies with vocational students (Van Houtte et al., 2012) since overall the whole group indicated that they felt more "bad" than "good". This was the lowest mean of the items and it slightly decreased, though not significantly, after the stress test. They also felt out of control and limited in their reach in English, which also was not significantly affected by the stress test. Because all three of these items were marked lower than others, and this low rating was true for most of the group, it does not seem to be an anomaly.

As noted, hospitality and tourism is a field in which high language skills distinguish workers for future upward mobility, given the need to interact with clients on a frequent basis (Baum, 2012). Such skill level takes time to develop, for which students must persist in their studies. How much can hospitality students expect to improve if they feel, on the very first day of class, bad about their own English levels in general, or out of control of their own progress, or limited overall? This sort of perception would clearly contribute to disengagement (Fernández, 
et al., 2010) and affect students' motivation. Ultimately it could contribute to vocational program abandonment, which should be further explored for direct connections.

\subsection{Objectives 2 and 3: Efforts as a Motor for Change, or a Call to Help?}

Students indicated that they felt strongly they could improve, even after a stress-test, and that they saw their progress and their troubles with English as mostly related to their efforts and practice rather than a talent or gift for languages, pointing to a more internal, controllable success/failure attribution. How can students feel badly, limited and out of control of their English, on the one hand, yet also indicate that they feel, very strongly, both before and after an achievement event, that they can improve through their own efforts, on the other? The contradictory response to this item on their ability to improve might be understood in a social light, as a call for attention, to establish a relationship with the instructor by recognizing their need for help. It would be a way of feasibly saying: I need help, but I am willing to extend effort.

This interpretation leans on the socially-constructed context of the study, which Barcelos (2011) and others (Wesely, 2012; Dweck, 2006) have indicated is important to student beliefs. The importance of social interplay and classroom dynamics in vocational students' motivation has been seen in other studies (Mulder et al., 2006; Tynjala \& Virtanen, 2008).

\subsection{Significance of Data for English for Vocational Studies Students}

The data in this study point to vocational students' beliefs about their success or failure in English as a foreign language as an important consideration for socially-constructed motivation, especially given that motivational problems have been targeted as one of the possible causes for drop-out in vocational programs in Spain. This is a particularly urgent problem given the high unemployment rate in Spain at $18.91 \%$ (Instituto Nacional de Estadística, 2016) and the expectation that this sector will continue to lead the economic recovery (World Economic Forum, 2015). Success in the programs that grow out of this demand will require more proficient and active English skills on a regular basis for career advancement (Baum, 2012), which places additional pressure on vocational students to succeed.

Importantly, these study results should contribute to a call for instructors to develop an awareness of the motivational beliefs that students create when studying English for occupational purposes, and to specifically be aware of how students may incorrectly attribute their failures or successes to fixed loci of control, wresting themselves of the belief that they have a hand in their learning process. Concretely, it is a clear call for instructors to pedagogically work with students on more positive attributions that give them agency in their learning process, which Dörnyei, has indicated is feasible (1994).

Affective factors like motivation are important to language learning, though, as Hutchinson and Waters indicate (1987) they are often ignored in vocational courses. A learner's individual needs to use the language as a tool, to take part in the demand for workers in hospitality and tourism which is growing today, is not created in a vacuum: it is molded by particularly social forces, as well as political and commercial currents, which continue to play out in the classroom environment. The way that society perceives these workers and their education logically trickles down into their own motivational attributions for their success and failure, which can contribute to their study persistence.

Unfortunately, a vocational teacher's labor is subject to similar social stigmas (Rasmussen, 2015) which have often resulted in the assumption that no qualification is needed to teach English VET learners (ibid). Unqualified teachers and a subsequent deregulation of English instructors in VET courses cannot feasibly help our learners, who may need in fact more individualized attention, and more specialized pedagogy than other foreign language students.

For this reason, a key part of our labor as instructors must occur off the paper and within the sphere of teacher/student interaction. This is to say that as an instructor one cannot lose the student to the course (relevance), or the market niche. This is especially important in vocational programs where instructors may focus on the very visual, end-goal of the class (restaurant vocabulary to serve, etc), given the concentration of content. Students are not simply these professional figures looming on the horizon. While they are seated in class, they are still in-progress, and some acknowledgement of the social construction of that interaction, and the role it has on student attributions and motivation, should be made. This is of particular importance for hospitality and service fields where real person-to-person, intercultural and thus complex, contact is expected of them.

It is also especially important in programs where societal impressions of vocational training in general, coupled with negative perceptions of language ability, as is the case in Spain, may combine in populations already experiencing acute difficulties: high unemployment, for example. This combination can be detrimental to the 
motivation of the students who try to persist in these programs, and may contribute to their "disengagement" (Fernández, Mena, \& Riviere, 2010) from it.

\subsection{Limitations and Future Research}

This study is exploratory, in that it examined key areas related to attribution theories for vocational students studying English for hospitality. Students participating in this study were a self-selected group and present a non-random sample.

For future research considerations, a future study focusing on attributions specifically concerning oral skills is needed, since this skill is key for hospitality/tourism students. Also, a larger study conducted on the attributions of vocational students in connection to finishing rates specifically for specific modules in hospitality is essential, as there is no national data available for what modules have higher rates of completion. This is particularly acute given the current the current economic situation worldwide and how this sector has been leading the economic recovery in many countries, particularly Spain. Concretely, a replicated study revisiting the students' attribution theories not simply before and after stress tests, but also at the end of the course would be interesting.

\section{Conclusions}

This study diversifies current research in motivation for vocational students studying English in the hospitality field in Spain in an area key to student beliefs: attribution theories. No previous research has focused on this area in vocational students in the hospitality sector, in particular. It indicates that students' views can be quite negative. In particular the ability to improve may be influenced by the expectation they have of their instructor as well as of the course itself. Instructors should take their role in students' development of attribution theories into consideration and help students make positive connections between their efforts and their success in the class, with a mind to improve their motivation, at the individual level, and, at the global level, improve course retention rates. In this way, they are contributing to a healthier learner and labor market, especially in areas of economic difficulty where VET training and English learning is essential to professional fields like tourism.

\section{References}

Arkin, R., Kolditz, T., \& Kolditz, K. (1983). Attributions of the test-anxious student: Self-assessments in the classroom. Personality and Social Psychology Bulletin. https://doi.org/10.1177/0146167283092012

Barcelos, A. M., \& Kalaja, P. (2011). Introduction to beliefs about SLA revisited. System, 39(3), 281-289. https://doi.org/10.1016/j.system.2011.07.001

Barcelos, A. M., \& Kalaja, P. (2003). Exploring possibilities for future research on beliefs about SLA. In A. M. F. Barcelos, \& P. Kalaja (Eds.), Beliefs about SLA: New research approaches (pp. 231-238). Kluwer Academic Publishers. https://doi.org/10.1007/978-1-4020-4751-0_1

Baum, T. (2012). Migrant workers in the international hotel industry. International Migration Paper 112. International Labour Office, International Migration Branch, Geneva, 2012.

Bharwani, S., \& Butt, N. (2012). Challenges for the global hospitality industry: an HR perspective. Worldwide Hospitality and Tourism Themes, 4(2), 150-62. https://doi.org/10.1108/17554211211217325

Comas-Forgas, R., Salva-Mut, F., Oliver-Trobat, M., \& Bauzà-Sampol, A. (2015). VET students drop-out: Academic performance and motivation as predictive factors. ICERI 2015 Proceedings. 2015, 1751. Retrieved from https://library.iated.org/view/COMASFORGAS2015VET.

Dörnyei, Z. (1994). Motivation and motivating in the foreign language classroom. The Modern Language Journal, 78(3), 273-284. https://doi.org/10.1111/j.1540-4781.1994.tb02042.x

Dörnyei, Z., Alastair, H., \& Muir, C. (2016). Motivational Currents in Language Learning: Frameworks for Focused Interventions. New York: Routledge.

Dudley-Evans, T., \& St. John, M. (1998). Developments in English for Specific Purposes: A Multidisciplinary Approach. Cambridge University Press: Cambridge.

Dweck, C. (2006). Mindset: The New Psychology of Success. New York: Ballantine Books.

Dweck, C. (2000). Self-theories: Their role in Motivation, Personality and Development. Philadelphia, PA: Taylor \& Francis.

European Commission. (2012). "Special Eurobarometer 386: Europeans and their languages," 2012. Retrieved from http://ec.europa.eu/public_opinion/archives/ebs/ebs_386_en.pdf 
European Commission. (2013). Work-based learning in Europe: Practices and policies. Retrieved from http://ec.europa.eu/dgs/education_culture/repository/education/policy/vocational-policy/doc/alliance/workbased-learning-in-europe_en.pdf

European Commission. (2014). Special Eurobarometer 417: European area of skills and qualifications. Retrieved from http://ec.europa.eu/COMMFrontOffice/publicopinion/index.cfm/Survey/getSurveyDetail/yearFrom/1974/ye $\operatorname{arTo} / 2014 /$ surveyKy/2015.

Fernández, M., Menaand Jaim, L., \& Riviere, J. (2010). School failure and dropouts in Spain. Social Studies Collection, 29. The La Caixa Foundation. Retrieved from https://multimedia.caixabank.es/lacaixa/ondemand/obrasocial/pdf/estudiossociales/vol29_en.pdf.

Gardner, R. (1984). The Social Psychology of Language: The Role of Attitudes and Motivation. London: Edward Arnold.

Graham, S. (2004). Giving up on modern foreign languages? Students' perceptions of learning French. The Modern Language Journal, 88(2), 171-190. https://doi.org/10.1111/j.0026-7902.2004.00224.x

Harris, R., \& Ramos, C. (2012). The one less traveled': Adult learners moving from the academic sector to the vocational sector in Singapore and Australia. Journal of Vocational Education \& Training, 64(4), 387-402. https://doi.org/10.1080/13636820.2012.691539

Horwitz, E. K. (1988). The beliefs about language learning of beginning university foreign language students. Modern Language Journal, 72(3), 283-294. https://doi.org/10.1111/j.1540-4781.1988.tb04190.x

Hosteltur. (2014). "Extremadura diseña un plan para posicionarse como destino gastronómico." Retrieved from https://www.hosteltur.com/145460_extremadura-disena-plan-posicionarse-como-destino-gastronomico.html

Hsieh, P., \& Schallert, D. (2008). Implications from self-efficacy and attribution theories for an understanding of undergraduates' motivation in a foreign language course. Contemporary Educational Psychology, 33, 513-532. https://doi.org/10.1016/j.cedpsych.2008.01.003

Hutchinson, T., \& Waters, A. (1987). English for Specific Purposes. Cambridge: Cambridge University Press. https://doi.org/10.1017/CBO9780511733031

Ibáñez, M., \& Suarí, J. (2013). Suspenso general en ingles. El Períodico Político. (Madrid, Spain). Retrieved from http://www.elperiodico.com/es/noticias/politica/suspenso-general-ingles-2661270

Ingle, S. \& Duckworth, V. (2013). Teaching and Training Vocational Learners. London: Sage.

Instituto Nacional de Estadística. (2016). "Encuesta de Población Activa (EPA): Tercer trimeste de 2016." Notas de Prensa de 27 de octubre de 2016. Madrid, Oct. 27, 2016.

Jordan, M., Lamamra, N., \& Masdonati, J. (2009). Dropout Rates in Vocational Education and Training: A Failure of the School-to-Work Transition? In Innovative Apprenticeships: Promoting successful school-to-work transitions, ed. Felix Rauner, et al. Turin: European Training Foundation, 57-61. Retrieved from http://www.bollettinoadapt.it/old/files/document/8670INAP.pdf

Kim, D. (2010). English for Occupational Purposes: One Language? Michigan: Bloomsbury Academic.

Lewis, C. (1982). Using the "Thinking Aloud" Method In Cognitive Interface Design. (Technical report).

Malhotra, N. (2004). Marketing Research: An Applied Orientation (4th ed.), New Jersey: Pearson Education, Inc.

Ministerio de Educación, Cultura y Deporte. (2016). Enseñanzas no universitarias. Formación Profesional. Curso 2013-2014. Retrieved

from http://www.mecd.gob.es/servicios-al-ciudadano-mecd/estadisticas/educacion/no-universitaria/alumnado/For macion-profesional/2013-2014.html

Mulder, R., Kahmann, K., Laubenbacher, S., \& Messmann, G. (2006). Characteristics of learning environments in secondary vocational education and the relation with work identity. Paper presented at the EARLI SIG Professional Learning and Development Conference, Heerlen, the Netherlands.

Peacock, M. (2010). Attribution and learning English as a foreign language. ELT Journal, 64, 184-193. https://doi.org/10.1093/elt/ccp031

Rasmussen, C. (2016). Improving the quality, capability and status of the VET teacher workforce. Retrieved from http://www.issinstitute.org.au/wp-content/media/2016/10/Rasmussen-Final-LowRes.pdf 
Schneiderman, N., Ironson, G., \& Siegel, S. (2005). Stress and health: Psychological, behavioral, and biological determinants. Annual Review of Clinical Psychology, 1, 607-628. https://doi.org/10.1146/annurev.clinpsy.1.102803.144141

Tran, L., \& Nyland, C. (2013). Competency-based training, global skills mobility and the teaching of international students in vocational education and training. Journal of Vocational Education \& Training, 65(1), 143-157. https://doi.org/10.1080/13636820.2012.755215

Triola, M. (2006). Elementary Statistics (10th ed.), Boston: Pearson.

Tynjala, P., \& Virtanen, A. (2012). Vocational students' motivation and perceived success in workplace learning. Presentation at the ECER conference From Teaching to Learning? Retrieved from http://www.eera-ecer.de/ecer-programmes/conference/1/contribution/1396/

Van Houtte, M., Demanet, J., \& Stevens, P. (2012). Self-esteem of academic and vocational students: Does within-school tracking sharpen the difference? Acta Sociologica, 55(1), 73-89. https://doi.org/10.1177/0001699311431595

Wang, Y. (2012). Education in a Changing World: Flexibility, Skills, and Employability. Washington, DC: World Bank. https://doi.org/10.1596/27092

Weiner, B. (1984). Principles for a theory of student motivation and their application within an attributional framework. Research on motivation in education, 1, 15-37.

Weiner, B. (2010). The development of an attribution-based theory of motivation: A history of ideas. Educational Psychologist, 45(1), 28-36. https://doi.org/10.1080/00461520903433596

Wesely, P. (2012). Learner attitudes, perceptions, and beliefs in language learning. Foreign Language Annals, 45, 98-117. https://doi.org/10.1111/j.1944-9720.2012.01181.x

World Economic Forum. (ND). (2015). Travel and Tourism Competitiveness Report 2015. Retrieved from $\mathrm{http} / /$ reports.weforum.org/travel-and-tourism-competitiveness-report-2015/index-results-the-travel-tourism -competitiveness-index-ranking-2015/

World Travel and Tourism Council. (2015). Economic Impact 2015: Spain. 2015. Retrieved from http://www.wttc.org/-/media/files/reports/economic\%20impact\%20research/countries\%202015/spain2015.p df

Wu, J. (2011). An Investigation and Analysis of Attribution Preference and Gender Difference of Non-English Majors' English Learning Based on Investigation of Non-English Majors in Tianjin Polytechnic University Journal of Language Teaching and Research, 2(2), 332-337.

Wu, Lin-Fang. (2014). College students' learning English for specific purposes courses through corpus building. English Language Teaching, 7(6). https://doi.org/10.5539/elt.v7n6p120

Yang, J.-T., Wan, C.-S., \& Yi-Jui, F. (2012). Qualitative examination of employee turnover and retention strategies in international tourist hotels in Taiwan. International Journal of Hospitality Management, 31(3), 837848. https://doi.org/10.1016/j.ijhm.2011.10.001

Youchang, H. (2007). Causal Attribution of Low Achievement in English among English Majors in Higher Vocational College. Journal of Guangdong Industry Technical College, 2007. Retrieved from http://en.cnki.com.cn/Article_en/CJFDTOTAL-HLJB201104072.htm

\section{Copyrights}

Copyright for this article is retained by the author(s), with first publication rights granted to the journal.

This is an open-access article distributed under the terms and conditions of the Creative Commons Attribution license (http://creativecommons.org/licenses/by/4.0/). 